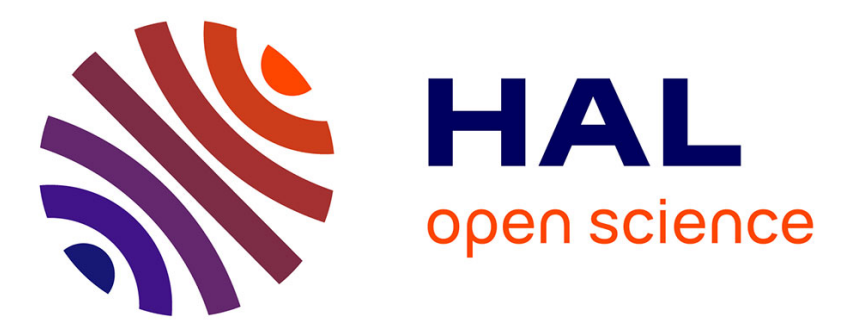

\title{
Influence of testosterone on precocious sexual development in immature rainbow trout
}

Marie-Hélène Magri, Aline Solari, Roland Billard, Pierrette Reinaud

\section{To cite this version:}

Marie-Hélène Magri, Aline Solari, Roland Billard, Pierrette Reinaud. Influence of testosterone on precocious sexual development in immature rainbow trout. General and Comparative Endocrinology, 1985, 57 (3), pp.411-421. 10.1016/0016-6480(85)90223-0 . hal-01600841

\section{HAL Id: hal-01600841 \\ https://hal.science/hal-01600841}

Submitted on 2 Jun 2020

HAL is a multi-disciplinary open access archive for the deposit and dissemination of scientific research documents, whether they are published or not. The documents may come from teaching and research institutions in France or abroad, or from public or private research centers.
L'archive ouverte pluridisciplinaire HAL, est destinée au dépôt et à la diffusion de documents scientifiques de niveau recherche, publiés ou non, émanant des établissements d'enseignement et de recherche français ou étrangers, des laboratoires publics ou privés.

\section{다(1)(2)}

Distributed under a Creative Commons Attribution - ShareAlikel 4.0 International 


\title{
Influence of Testosterone on Precocious Sexual Development in Immature Rainbow Trout ${ }^{1}$
}

\author{
Marie-Hélène Magri, Aline Solari,* Roland Billard, and Pierrette Rfinaun \\ Laboratoire de Physiologie des Poissons and *Station de Physiologie Animale Institut National de la \\ Recherche Agronomique (INRA) 78350 Jouy-en-Josas, France \\ Accepted June 5, 1984
}

\begin{abstract}
The influence of testosterone on plasma and pituitary levels of gonadotrophin (GiH) as well as on gonadal development was studied in immature rainbow trout. Among the animals receiving a testosterone-cocoa butter implant $(200 \mu \mathrm{g})$ at the age of 5 months, gonadal puberty occurred 8 months later in half of the males (opposite to the controls which remained immature) and the beginning of oocyte maturation was observed in only one female. These animals were characterized by a higher pituitary GTH level. Owing to the multivariate statistical analyses made, it was possible to provide evidence for the presence of two populations with different reactions to the same steroid trcatment. They also confirmed the existence of a positive testosterone fcedback, in the male, leading to a precocious gonadal development. The pituitary GTI load obtained with $200 \mu \mathrm{g}$ of testosterone seemed to be related to the age at first maturation. The secretion of an appropriate level of GTH resulting in the stimulation of gametogenesis required the availability of a relatively large pituitary GTH level and seemed to be possible because the animals were already in the pubertal period. The fact that the highest pituitary GTH level of the treated lot was found in the only female showing a beginning of sexual maturation suggests that testosterone may also act in females. 1985 Acadomic Press, Ine.
\end{abstract}

In immature but already sexually differentiated teleosts, the effects of sexual steroids on gametogenesis vary according to species and experimental conditions (i.e., doses, mode of administration, treatment time and length).

Injection of estrogens seemed to stimulate growth of oocytes in the silver eel (Olivereau and Olivereau, 1979a) and gonial divisions and vitellogenesis in the carp (Pantic and Lovren, 1978), but had no effect in rainbow trout (Upadhyay, 1977; Billard et al., 1982; Sower et al., 1983) and led to cessation of vitellogenesis in pink salmon (Funk et al., 1973).

Androgens stimulated spermatogenesis in Poecilia latipinna (Van den Hurk and Van de Kant, 1975) and in Oryzias latipes (Hamaguchi, 1979) as well as in salmonids such as Oncorhynchus kisutch (Fagerlund

${ }^{1}$ Translated by K. Rerat. and McBride, 1977), Oncorhynchus tshawytscha (Schreck and Fowler, 1982), and Salmo gairdneri (Fagerlund and McBride, 1977; Crim and Evans, 1982, 1983; Sower et al., 1983). In Salmo salar, the percentage of maturc males increased after treatment with testosterone (Crim and Peter, 1978; Dodd et al., 1978). In hypophysectomized Poecilia reticulata (Pandey, 1969), P. latipinna (Van den Hurk and Van de Kant, 1975), and O. latipes (Hamaguchi, 1979), the mitotic divisions of the spermatogonial cells went on after androgen treatment. The multiplication of spermatogonial cells was not altered by methallibure in $P$. latipinna (Van den Hurk and Van de Kant, 1975) or cyproterone acetate in O. latipes (Hamaguchi, 1979). Large doses of methyltestosterone incorporated into the food, on the other hand, led to a degeneration of the testes (decrease in the number of spermatogonia, hypertrophy of the tissues) in $O$. 
Kisutck (McBride and Fagerlund, 1973, Fagerlund and McBride, 1977; Higgs et al., 1977; Yu et al., 1979), O. gorbusha, O keta (Yamasaki, 1972), S. gairdneri (Billard et al., 1982; Sower et al., 1983), and Carassius auratus (Takahashi, 1972).

Ultrastructural and immunocytochemical studies of the pituitary gonadotrophic cclls and assessment of pituitary and plasma levels of gonadotrophin (GTH) give information about the mode of action of steroids in immature animals: pituitary GTH increased after steroid treatment (Atlantic salmon: Crim and Peter, 1978; rainbow trout: Crim and Evans, 1979, 1980, 1982, 1983; Crim et al., 1981; Gielen et al., 1981; Gielen and Goos, 1983; eel: Dufour et al., 1983a) and the pituitary gonadotrophic cells were stimulated (sockeye salmon: Van Overbreeke and McBride, 1971; rainbow trout: Gielen et al., 1982; eel: Olivereau and Chambolle, 1978, 1979; Sokolowska et al., 1978; Olivereau and Olivereau 1979a and b; carp: Pantic and Lovren, 1978). Like cxogenous steroids, GTH or pituitary extracts led to an increase in the pituitary GTH level and a maturation of the gonadotrophic cells in male trout (Crim et al., 1982; Gielen et $a l ., 1982)$ and female eel (Olivereau and Fontaine, 1966; Olivereau, 1967; Ueda and Takahashi, 1978; Dufour et al., 1983b). The gonadal steroids were responsible for this increase of pituitary GTH in male trout (Crim et al., 1982; Gielen et al., 1982). According to Crim and Evans (1983), plasma GTH levels increased after testosterone treatment.

The aim of the present work was to study the effects of testosterone on pituitary and plasma levels of GTH and on gonadal development in order to contribute to the understanding of the role of this steroid at the onset of puberty in rainbow trout.

\section{MATERIALS AND METHODS}

The rainbow trout used were 5 months old and weighed 5-10 $\mathrm{g}$ in July 1981 . The stock from which they were taken was characterized by a sex ratio of
$1: 1$ and by a percentage of first maturation at 2 years (during the winter of 1982-1983) of 54\% for the males and $9 \%$ for the females (Chevassus, personal communication).

The study took place at the experimental fish farm of "Gournay sur Aronde" under natural photoperiod and temperature conditions. In July 1981, one lot of animals received an injection of cocoa butter alone (control, $n=192$ ) and another one, cocoa butter combined with testosterone (experimental, $n-166$ ) according to the method described by Billard and Peter (1977) and Crim and Evans (1979). Testosterone (17ßhydroxyandrostan-4-ene-3-one, Rousscl), dissolved in molten cocoa butter, was injected intraperitoneally at the level of the pelvic fins at a dose of 200 $\mu \mathrm{g}$ in a volume of $200 \mu \mathrm{l}$. The presence of the solid implant within the perivisceral cavity was confirmed at the end of the experiment ( $95 \%$ positive results).

In March 1982, the effects of the treatment were analyzed and the criteria used were, on the one hand. the number of females having ovulated or the number of spermiating males in the whole population $(n=358)$ and, on the other hand, the body weight, gonadal weight, and histological stage, as well as the plasma and pituitary levels of GTH in the 55 sacrificed animals.

\section{Gonadotropic Hormone Determination}

Blood samples were collected in heparinized sy. ringes at the level of the caudal vascularization. Immediately after their withdrawal, pituitaries were ground in $500 \mu \mathrm{l}$ saline. Samples of blood and pituitary homogenates were stored over crushed ice and centrifuged. The blood plasma and pituitary supcrnatants were removed and stored at $-20^{\circ} \mathrm{C}$ until analyzed.

Pituitary and plasma levels of maturational glycoprotein GTH were determined by radioimmunoassay according to Breton et al. (1971) using an antibody produced against pure trout GTH (t-GTH; Breton et al., 1976). The hormone used for labeling and establishment of standard curves was a purified salmon GTH hormone (Breton et al., 1978).

\section{Determination of the State of \\ Gonad Development}

The gonads fixed in Bouin-Holland's fluid were dehydrated and embedded into paraplast. The 5- $\mu \mathrm{m}$ thick sections were stained with Regaud's hematoxyline, orange $\mathrm{G}$, aniline blue for the males and with Heindenhein's Azan for the females (Gabe, 1968).

\section{Statistical Analysis}

Classical statistical methods for a separate analysis of each variable were used in the first study involving results obtained in males and females (calculation of mean values, standard deviations, standard errors, 
and coefficients of variation, comparison of groups by analysis of variance or by the Mann-Whitney ( $U$ test). The data obtained with males were further studied using methods of multivariate analysis (Solari et al., 1982; Lefebvre, 1983). These methods are based on the overall analysis of all measured variables and not on the separate study of each parameter as in classical statistics. The first method used was that of centered data. It is a descriptive method supplying a spatial graphical representation both of the animals and of the five measured biological variables (body weight, gonadal weight, state of gonads, plasma GTH, piluitary GTH). Owing to the more or less remote position of the individuals within the space, it was possible to form groups with the same characteristics. The position of the variables within the space may account for the difference between the groups of individuals.

The method of discriminating functions was used in addition to that of centered data when the difference between two groups could not be easily explained only by the position of the variables within the space. Those functions were linear functions of the biological variables by means of which new variables $(y)$, the so called discriminant variables, may be calculated.

The programs used for these multivariate analyses were developed by Lefebvre et al. (1981) and the data processed on the microcomputer Wang 2200P.

\section{RESULTS}

In March 1982 no female, among the 166 testosterone-treated animals, had ovulated, while 40 males (i.e., $50 \%$ of the males) produced sperm. No sexual maturation was observed in the 192 control animals.

\section{Males}

In the twenty-six males sacrificed in March 1982, the statistical analysis of each variable scparately showed that there was a large heterogencity within each of the two lots (control and experimental), especially in the experimental (testosterone treated) one (Table 1). In the latter, this heterogeneity led to coefficients of variation exceeding $50 \%$ for all measured variables, except body wcight (Tabie 1).

As the larger dispcrsion in the treated lot could result from the presence of several populations with different reactions towards testosterone, an analysis of the centered dala was made in order to show the existence of these populations (Fig. 1). The position of each of the 26 males within the space of the first three canonical axes (which are linear functions of the biological variables) clearly shows that the treated animals can be divided into two groups: seven animals around the controls and nine completely discriminated in another area of the space. The histological examination of testes showed that these nine animals were all mature; a great number of spermatozoa were already present in the lobular lumen (Fig. 2b). Just before sacrifice, semen could be collected by abdominal pressure. These animals exhibited the heaviest gonads and the highest pituitary GTH levels (Table 2). On the other hand, the control and experimental animals grouped in another area of the space, were all immature. The germ cells of the testes were only spermatogonia (Fig. 2a). However, the lestosteronetreated immature trout showed pituitary GTH levels between those of the controls and of the "testosterone-mature" animals (Table 2).

TABLE 1

In the Males, Influence of Testostlrone on Body Whight, Gonadal. Weigh'l, Plasma and Pitumtary GTH

\begin{tabular}{ccccc}
\hline Treatment & $\begin{array}{c}\text { Body weight } \\
(\mathrm{g})\end{array}$ & $\begin{array}{c}\text { Gonadal weight } \\
(\mathrm{g})\end{array}$ & $\begin{array}{c}\text { Plasma GTII } \\
(\mathrm{ng} / \mathrm{ml})\end{array}$ & $\begin{array}{c}\text { Pituitary GTH } \\
\text { (ng/pituitary) }\end{array}$ \\
\hline $\begin{array}{c}\text { Control } \\
(n=9)\end{array}$ & $104.0 \pm 9.3$ & $0.066 \pm 0.007$ & $1.6 \pm 1.1$ & $3.2 \pm 0.3$ \\
Testosterone & $(27)$ & $(34)$ & $(211)$ & $(24)$ \\
$(n=17)$ & $77.4 \pm 5.5$ & $0.712 \pm 0.202$ & $1.4 \pm 0.2$ & $51.9 \pm 6.8$ \\
& $(29)$ & $(117)$ & $(72)$ & $(54)$ \\
\hline
\end{tabular}

Note. Values are means \pm SEM. Values in parentheses are coefficients of variation (\%). 


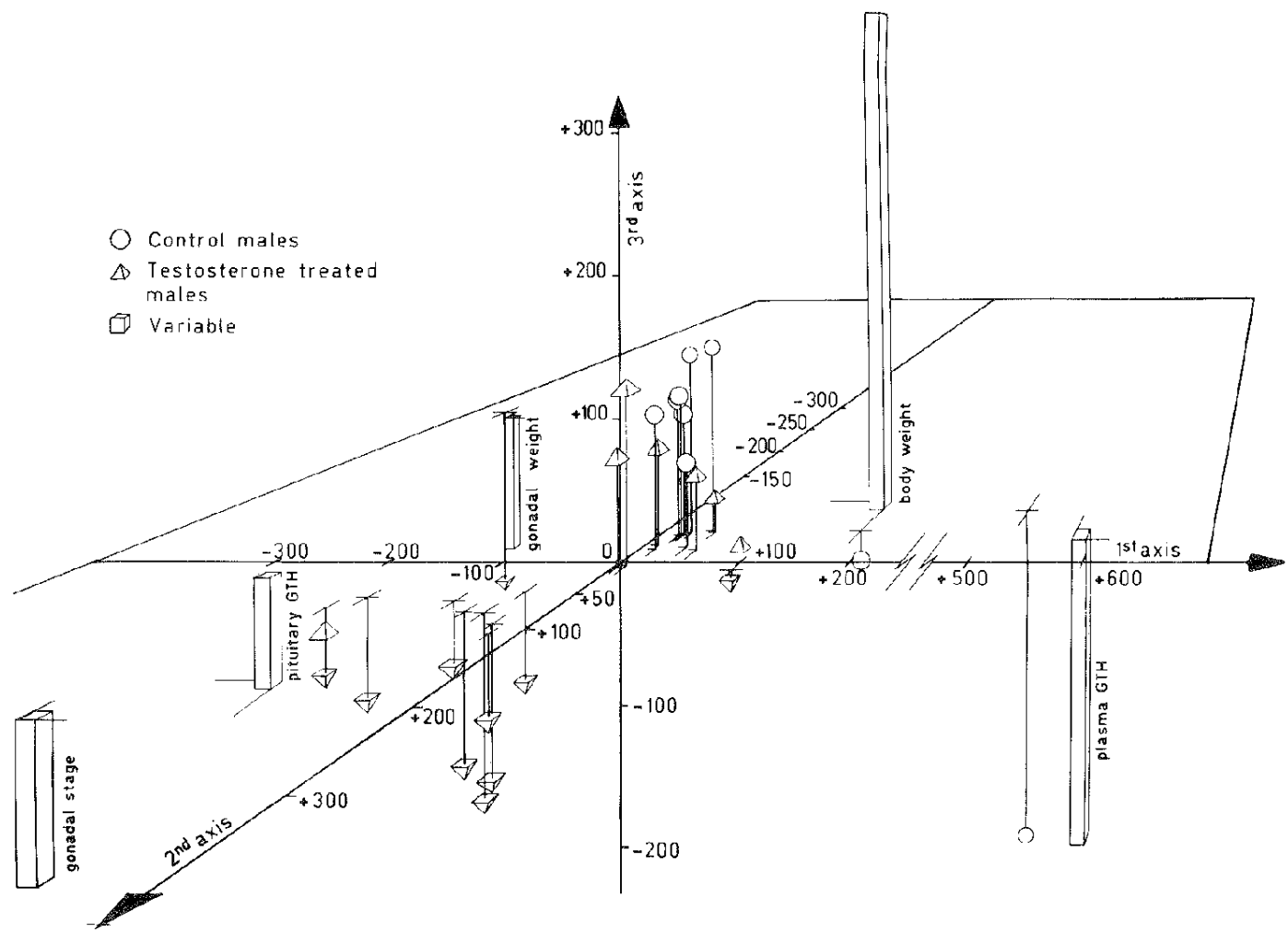

FIG. 1. Position of the five biological variables and distribution of the 9 control males and 17 testosterone-treated males in a three-dimensional space. This space is defined by the first three canonical axes obtained from linear combinations of the five biological variables. This graph shows that the testosterone-treated animals can be divided into two groups, i.e., one far from the controls, one close to the controls.

Among the testosterone-treated and mature animals, one individual with an exceptionally high gonadal weight $(3.51 \mathrm{~g})$ was different from the others and was located almost at the same place as the "gonadal weight variable." Likewise, a control animal could be distinguished from the others because of its high plasma G'I'H level (9.9 ng/ml; Fig. 1).

With the aim of determining the different variables involved in the separation of the groups, the analysis was continued via the search for discriminant functions (Fig. 3). It was confirmed that pituitary GTH and gonadal weight intervened systematically in the separation of the three isolated groups by the method of centered data (controls, "testosterone-immature," "testosteronemature") and this intervention was strong enough to isolate the "testosterone-mature" group from the controls. For separating the "testosterone-immature" group

FIG. 2.(a) Section of a testis from a control or "testosterone immature" animal. The germ cells are only spermatogonia $(\mathrm{Sg})(\times 280)$. (b) Section of a testis from a "testosterone mature" animal. Spermatozoa $\left(S_{2}\right)$ are present in the lobular lumen $(\times 280)$. (c) Portion of an ovary with previtellogenic follicles (Pv) from a control or testosterone-treated animal $(\times 140)$. (d) Portion of the ovary from the only testosterone-treated female showing follicles at a more advanced stage. i.e., formation of yolk vesicles (Yv) and oil droplets (Od) $(\times 140)$. 


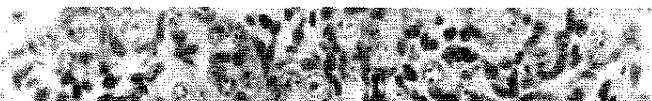

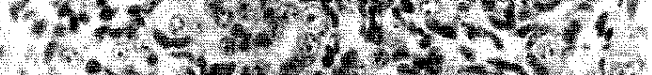

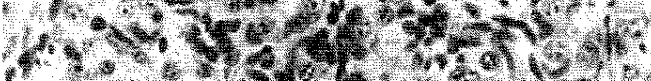

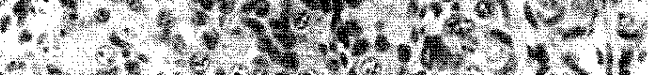

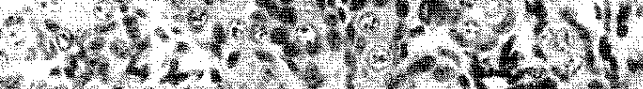

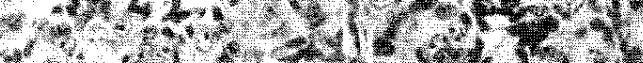

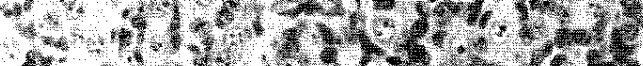

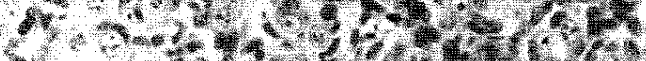

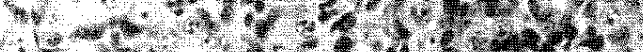

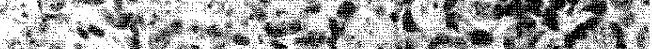

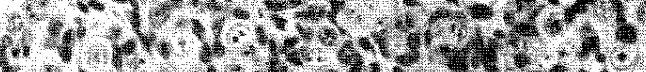

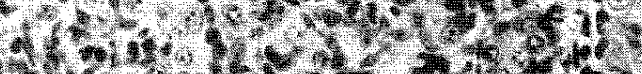

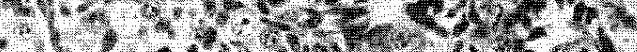

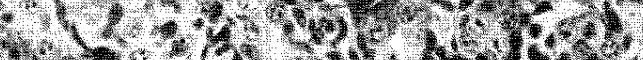

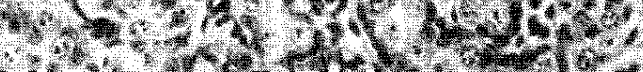

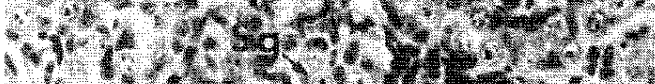

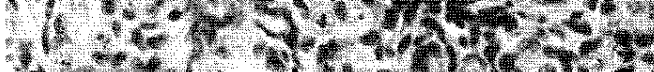

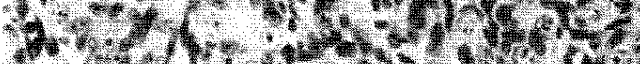

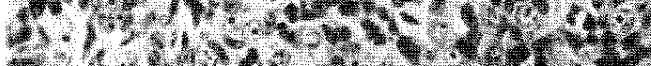

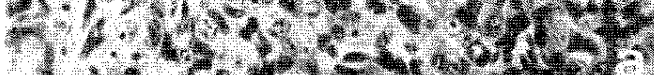
$3 u^{2}$.
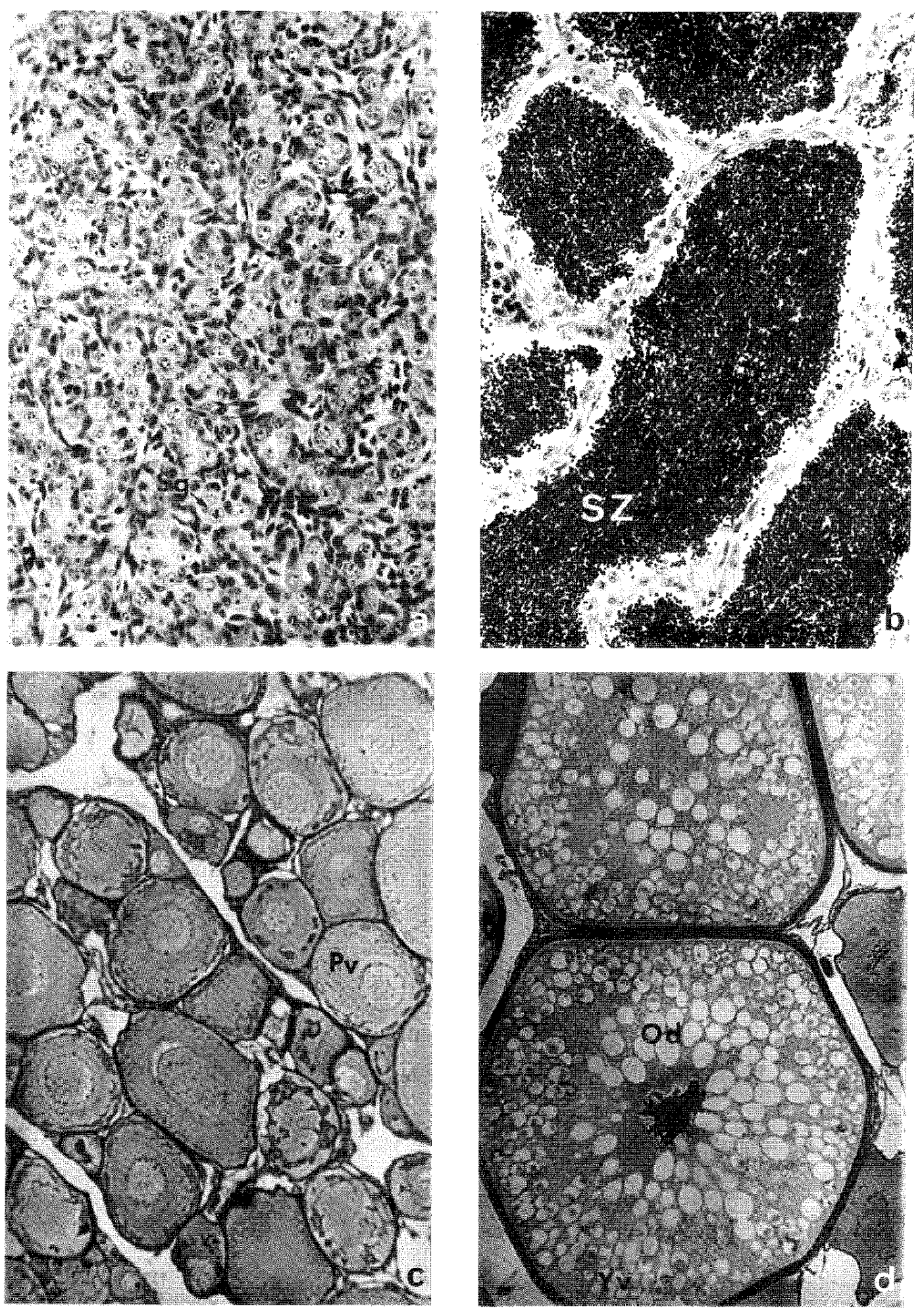
TABLE 2

Mean Values of the Variabies Measured in Control. and 'Ieśrosterone-Treated Immatlre and Mature Males

\begin{tabular}{|c|c|c|c|c|}
\hline Treatment & $\begin{array}{l}\text { Body weight } \\
(\mathrm{g})\end{array}$ & $\begin{array}{l}\text { Gonadal weight } \\
\text { (g) }\end{array}$ & $\begin{array}{c}\text { Plasma } \\
\text { GTH } \\
(\mathrm{ng} / \mathrm{ml})\end{array}$ & $\begin{array}{c}\text { Pituitary } \\
\text { GTH } \\
\text { (ng/pituitary) }\end{array}$ \\
\hline $\begin{array}{l}\text { Control } \\
\qquad(n=9)\end{array}$ & $\begin{array}{c}104.0=9.3 \\
(27)\end{array}$ & $\begin{array}{c}0.066 \pm 0.007 \\
(34)\end{array}$ & $\begin{array}{c}1.6 \pm 1.1 \\
(211)\end{array}$ & $\begin{array}{c}3.2 \pm 0.3 \\
(24)\end{array}$ \\
\hline $\begin{array}{l}\text { Testosterone } \\
\text { "Immature" } \\
(n=7)\end{array}$ & $\begin{array}{c}78.8 \pm 8.9 \\
(30)\end{array}$ & $\begin{array}{c}0.084 \pm 0.025 \\
(77)\end{array}$ & $\begin{array}{c}0.8 \pm 0.3 \\
(104)\end{array}$ & $\begin{array}{c}22.2 \pm 4.9 \\
(58)\end{array}$ \\
\hline $\begin{array}{l}\text { "Mature" } \\
(n=10)\end{array}$ & $\begin{array}{c}76.4+7.3 \\
(30)\end{array}$ & $\begin{array}{c}1.151 \pm 0.267 \\
(73)\end{array}$ & $\begin{array}{c}1.8 \pm 0.3 \\
(52)\end{array}$ & $\begin{array}{c}72.6 \pm 3.5 \\
(15)\end{array}$ \\
\hline
\end{tabular}

Note. The subdivision of the "testosterone" lot results from the multivariate analysis. Values are means \pm SEM. Values in parentheses are coefficients of variation $(\%)$.

from the controls, the body weight played a part in addition to the former two variables. Plasma GTH only intervened for a better discrimination between testosteronetreated mature and immature animals.
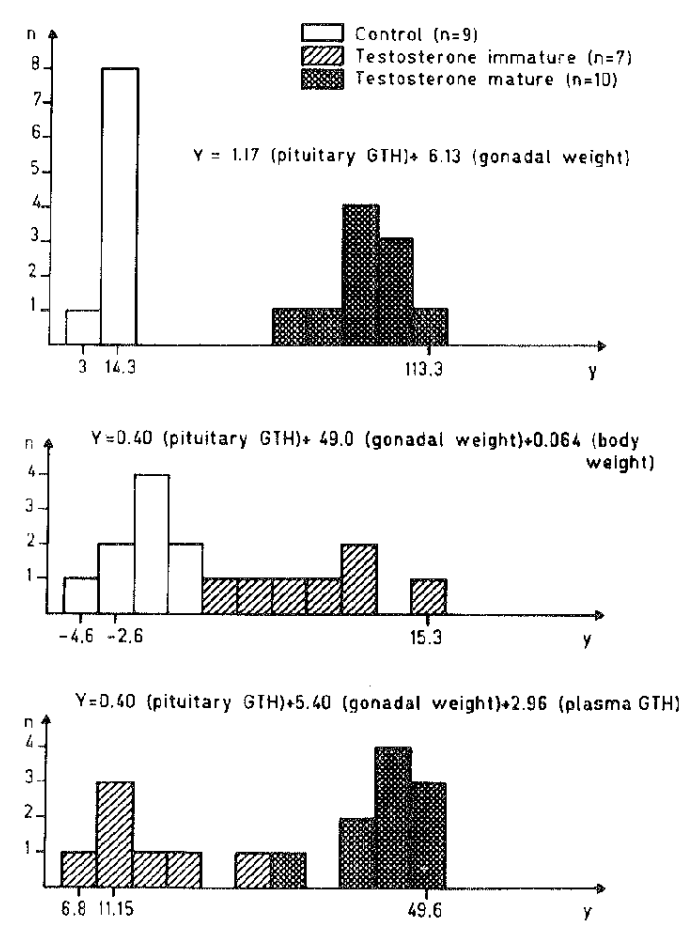

FIG. 3. Frequency histogram of the discriminant variable $y$ (the discriminant variable $y$ for each male is obtained by replacing the value of each biological variable in the discriminant function Y): $n=$ number of males.

\section{Females}

Control as well as testosterone-treated lemales (except one) were immature, in the state of previtellogenesis (Fig. 2c). With regard to body weight and plasma GTH (Table 3), the univariate statistical analysis did not show any difference between control and treated lots. Plasma GTH was rather variable in the two lots (from 0 to 5.5 $\mathrm{ng} / \mathrm{ml}$, coefficient of variation $>90 \%$ ).

Pituitary GTH levels in the treated females were significantly higher than those of the controls $(P<0.05)$. In the testosterone lot, the coefficient of variation was $87 \%$. This high variability revealed the large heterogeneity of the pituitary responses to the steroid: $65 \%$ of the treated females (11/17) showed the same range of pituitary levels as the controls; the six other treated females exhibited higher pituitary G'TH levels (from 18 to $49.3 \mathrm{ng} /$ pituitary) than the controls. Beginning of vitellogenesis could only be observed in the female with the highest GTH level (49.3 ng/pituitary; Fig. 2d).

\section{Comparison between Male and Female}

Pituitary GTH Levels (Tables 2,3)

The pituitary levels of GTH were significantly higher in control females than in control males $(P<0.005)$. However, after 
TABLE 3

In the Females, Influence of Testosterone on Body Weight, Gonadnl Weight, Plasma and PItllitary GTH

\begin{tabular}{ccccc}
\hline Treatment & $\begin{array}{c}\text { Body weight } \\
(\mathrm{g})\end{array}$ & $\begin{array}{c}\text { Gonadal weight } \\
(\mathrm{g})\end{array}$ & $\begin{array}{c}\text { Plasma } \\
\text { GTH } \\
(\mathrm{ng} / \mathrm{ml})\end{array}$ & $\begin{array}{c}\text { Pituitary } \\
\text { GTH } \\
\text { (ng/pituitary) }\end{array}$ \\
\hline Control & $96.6 \pm 7.3$ & $0.141 \pm 0.100$ & $0.8 \pm 0.5$ & $6.3+0.9$ \\
$(n=11)$ & $(26)$ & $(42)$ & $(224)$ & $(48)$ \\
Testosterone & $79.3 \pm 7.7$ & $0.146 \pm 0.040$ & $1.1 \pm 0.2$ & $16.3 \pm 3.5$ \\
$(n=18)$ & $(41)$ & $(23)$ & $(92)$ & $(87)$ \\
\hline
\end{tabular}

Note. Values are mcans \pm SEM. Values in parentheses are coefficients of variation (\%).

steroid treatment, the pituitary GTH level of the mature males was higher than that of the females $(P<0.005)$. On the other hand, the levels of the immature treated males and those of the treated females were the same.

\section{DISCUSSION}

After administration of a single implant of testosterone at the age of 5 months, gonadal puberty occurred 8 months later in half of the males (i.e., 1 or 2 years before the normal date of first reproduction). These animals were characterized by a higher level of pituitary GTH. Use of discriminant functions showed that the plasma level of GTH also intervened in the separation of these mature males from the immature ones. A high pituitary GTH level in relation to the onsct of gonadal maturation was observed in only one femalc.

According to our results, the hypothesis of a direct stimulation of the testes by exogenous testosterone should be rejected. Indeed, only part of the individuals exhibited spermatogenesis while the testes of all animals had already reached a sufficient degree of differentiation for production of gametes and secretion of sexual steroids, as affected by gonadotrophin (Magri et al., unpublished data). The mechanism of indirect action of testosterone could be the following: accumulation of GTH in the pituitary gland, rclcase of GTH into the blood circulation, and, at last, stimulation of gametogenesis.

\section{Accumulation of GTH in the Pituitary Gland}

According to data from the literature, the same dose of steroid leads to large individual variations in the level of pituitary GTH (c.g., Crim et al., 1981; Dufour et al., 1983a). Our results, obtained with $200 \mu \mathrm{g}$ of testosterone or with $20 \mu \mathrm{g}$ (Magri et al., unpublished data), reveal the cxistence of two populations with different pituitary GTH responses induced by the steroid. In the females, one group gave the same pituitary response as the controls and in another group, the response was higher. The males could also be distributed into two groups: one with a higher pituitary GTH level and another group with a much higher level than that of the controls. This heterogeneity, which is marked for the two sexes, might reveal the existence of genetic differences in relation to the age at puberty. In the stock of fish used, $54 \%$ of the males and $9 \%$ of the females were sexually mature at the age of 2 years, the others at 3 or 4 years (Chevassus, personal communication). The population of individuals with the same response as the controls (f) or exceeding it $(\vec{b})$ corresponded to latc-maturing animals ( 3 or 4 years), and those with a superior ( $(9)$ or highly superior (d) response corresponded to early-maturing animals (2 years). According to our results, there was a large difference between "early-maturing" males and females in the pituitary sensitivity towards the steroid; the 
pituitary GTH level of the males exceeded that of the females and this was all the more marked as the level was higher in March in female controls.

These considerations can be compared with the results obtained in the platyfish, where the more or less late-maturation processes are controlled by a gene P (Kallman and Schreibman, 1973; Kallman et al., 1973; Schreibman and Kallman, 1978). The sequence of luteinizing hormone-releasing hormone (LH-RH) appearance in the brain (Schreibman et al., 1982a and b; HalpernSebold and Schreibman, 1983), the development of the gonadotrophic area in the pituitary (Schreibman and Kallman, 1978), and the response of gonadotrophic and germinal cells to cxogenous LH-RH (Bao and Kallman, 1982) follow a more or less precocious temporal scheme depending on the genotype of the animal.

Thus, the magnitude of the pituitary GTH response, as affected by testosterone, seems to depend on the age at puberty, but it also depends on the steroid dose used: pituitary gonadotrophin increased with increasing doses of testosterone (from 0.2 to $20 \mu \mathrm{g}$ ) (Crim and Evans, 1979). The doseresponse effect exists at higher doses since the pituitary GTH level reached 8 months after administration of $200 \mu \mathrm{g}$ of testosterone was about four times higher than that obtained with $20 \mu \mathrm{g}$ after 1 month (Magri et al., unpublished data). When very high doses of testosterone were administered ( 3 or $7 \mathrm{mg}$ ), the pituitary GTH increased very rapidly and remained high during the 3-4 months of study performed by Crim and Evans $(1982,1983)$. With the dose of $200 \mu \mathrm{g}$ testosterone, our experimental design did not supply any information about the variation in the pituitary GTH level according to time. It was therefore impossible to determine whether the pituitary level reached a maximum during the first months and then decreased, as it did 1 month after administration of $20 \mu \mathrm{g}$ testosterone (Magri et al., unpublished data).

\section{Release of GTH Accumulated in the Pituitary Gland}

The statistical method of multivariate analysis shows the role of plasma GTH in the separation of mature from immature males. Thus, in some of these individuals, GTH was released from the pituitary and this release was confirmed by the onset and achievement of spermatogenesis. It was in these animals that the highest pituitary GTH levels were recorded. The results of Crim and Evans (1983) obtained with $7 \mathrm{mg}$ testosterone clearly show the existence of a positive testosterone feedback on the gonadotrophic function since very high plasma levels of GTH $(10-20 \mathrm{ng} / \mathrm{ml})$ were reached from very large contents of pituitary GTH. All these results show that the existence or detection of gonadotrophin secretion in the circulation require the availm ability of a sufficiently large mobilizable pituitary load induced by an adequate steroid stimulation.

The mechanism of indirect action of testosterone envisaged for males could be applied to females, but would perhaps require larger steroid doses and treatment lengths. Indeed, the beginning of vitellogenesis was observed in a female whose pituitary GTH level exceeded that of the other individuals remaining in the state of previtellogenesis.

In conclusion, owing to an appropriate pituitary GTH load, it was possible to obtain a secretion of GTH in the circulation capable of inducing a precocious spermatogenesis. However, this secretion seemed only to be possible because the animal was already in the pubertal period. Indced, the period during which the experiment took place was considered as a period of initiation of the gonadotrophic function (Magri et al., unpublished data). This suggests that during that period, the hypothalamo--pituitary system becomes progressively able to 
respond to high doses of testosterone by an adequate secretion of GIH in the circulation. In that case, the positive action of testosterone on the gonadotrophic function and on the gonadal development constitutes, in the young, one of the endocrine adjustments of the pubertal period (for instance, via the clcration of the pituitary GTH level during pubcrty observed in precocious Atlantic salmon, (Crim and Evans, 1978; Stuart-Kregor et al., 1981)) but not the cause of puberty.

\section{ACKNOWLEDGMENTS}

The authors gratefully acknowledge the useful advice of Mr. Marie, the assistance and cooperation of Mr. Burger for the animal care. Mrs. Zambroni and Mr. Breton for the radioimmunoassays, Mrs. Boitard and Mr. Lefebvre for statistical analyses, Miss du Créhu for the typewriting, and Mr. Gallé, Mr. Slagmulder and Mr. Scandolo for the illustration of the manuscript.

\section{REFERENCES}

Bao, I. Y., and Kallman, K. D. (1982). Genetic control of the hypothalamo-pituitary axis and the effect of hybridization on sexual maturation (Xiphophorus, pisces, Poeciliidae). J. Exp. Zool. 220 , 297-309.

Billard, R., and Peter, R. E. (1977). Gonadotropin re lease after implantation of anti-estrogens in the pituitary and hypothalamus of goldfish, Carassius auratus. Gen. Comp. Endocrinol. 32, 213-220.

Billard, R., Richard, M., and Rombauts, P. (1982). Inhibition of spermatogenesis and vitellogenesis in rainbow trout by hormonal additives in the diet. Prog. Fish-Cult. 44(1), 15-18.

Breton, B., Jalabert, B., and Reinaud, P. (1976). Purification of gonadotropin from rainbow trout (Salmo gairdneri R.) pituitary glands. Ann. Biol. Anim., Biochim., Biophys. 16, 25-36.

Breton, B., Prunet, P., and Reinaud, P. (1978). Sexual differences in salmon gonadotropin. Ann. Biol. Anim., Biochim., Biophys. 18(4), 759-765.

Breton, B., Kann, G., Burcawa-Gerard, E., and Billard, R. (1971). Dosage radioimmunologique d'une hormone gonadotrope de carpe (Cyprinus carpio L.). C.R. Acad. Sci. (Paris) Ser, D 272, 1515-1517.

Crim, L. W., and Evans, D. M. (1978). Seasonal levels of pituitary and plasma gonadotropin in male and female atlantic salmon parr. Canad. J. Zool. 56, $1550-1555$.
Crim, L. W., and Evans, D. M. (1979). Stimulation of pituitary gonadotropin by testosterone in juvenile. rainbow trout Salmo gairdneri. Gen. Comp. Endocrinol. 37, 192-196.

Crim, L. W., and Evans, D. M. (1980). LH-RH-stimulated gonadotropin release from the rainbow trout pituilary gland: An in vitro assay for detection of teleost gonadotropin releasing factor(s). Gen. Comp. Endocrinol. 40, 283-290.

Crim, L. W., and Evans, D. M. (1982). Positive steroid fcedback on gonadotropic hormone in juvenile rainbow trout: Evidence of gonadotropin synthesis and release following testosterone administration via Silastic capsules. In "Proceedings, International Symposium on Reproductive Physiology of Fish. Wageningen, the Netherlands 2-6 August, 1982" (C. J. J. Richter and H. I. Th. Goos, eds.), p 23. Pudoc, Wageningen.

Crim, L. W., and Evans, D. M. (1983). Influence of testosterone and/or luteinizing hormone releasing hormone analogue on precocious sexual development in the juvenile rainbow trout. Biol. Reprod. $29,137-142$.

Crim, L. W., and Peter, R. E. (1978). The influence of testosterone implantation in the brain and pituitary on pituitary gonadotropin lcvels in Atlantic salmon parr. Ann. Biol. Anim., Biochim., Biophys. 18, 689-694.

Crim, L. W., Peter, R. E., and Billard, R. (1981), Onset of gonadotropic hormone accumulation in the inmmature trout pituitary gland in response to estrogen or aromatizable androgen steroid hormones. Gen. Comp. Endocrinol. 44, 374-381.

Crim, L. W., Billard, R., Genge, P. D., and Idler, D. R. (1982). The influence of immature gonads on onset of gonadotropic hormone accumulation in the juvenile rainbow trout pituitary gland. Gen. Comp. Endocrinol. 48, 161-166.

Dodd, J. M., Stuart-Kregor, P. A. C. Sumpter, J. P., Crim, L. W., and Peter, R. E. (1978). Premature sexual maturation in the Atlantic salmon Salmo salar L. In "Comparative Endocrinology" (P. J. Gaillard and H. H. Bocr, eds.) pp. 101-104. F.Isevier/North IIolland Biomedical Press, Amsterdam.

Dufour, S., Delerue-Le Belle, N., and Fontaine, Y. A. (1983a). Effects of steroid hormones on piluitary immunoreactive gonadotropin in european freshwater eel Anguilla anguilla L. Gen. Comp. Endocrinol. 52, 190-197.

Dufour, S., Delerue-Le Belle, N., and Fontaine, Y. A. (1983b). Development of a heterologous radioimmunoassay for eel (Anguilla anguilla) gonadotropin. Gen. Comp. Endocrinol. 49, 404-w13.

Fagerlund, U. H. M., and McBride, J. R. (1977). ECfect of $17 \alpha$ methyltestosterone on growth, gonad 
development, external fcatures and proximate composition of muscle of steelhead trout, coho and pink salmon. Tech. Rep. Fish. Mar. Serv. Canad. 716.

Funk, J. D., Donaldson, E. M., and Dye, H. M. (1973). Induction of precocious sexual development in female pink salmon (Oncorhynchus gorbuscha). Canad. J. Zool. 51, 493-500.

Gabe, M. (1968). "Techniques Histologiques." Masson, Paris.

Giclen, J. Th., Goos, H. J. 'Lh., Peute, J., Van Den Bosch, R. A., and Van Oordt, P. G. W. J. (1982). The brain-pituitary-gonadal axis in the rainbow trout, Salmo gairdneri: Gonadal hormones and the maturation of gonadotropic cells. Cell Tissue Res. 225, 45-56.

Gielen, J. Th., and Goos, H. J. Th. (1983). The brainpituitary-gonadal axis in the rainbow trout, Salmo gairdncri, II. Direct effect of gonadal steroids on the gonadotropic cells. Cell Tissue Res. $233,377-388$.

Halpern-Sebold, L. R., and Schreibman, M. P. (1983). Ontogeny of centers containing luteinizing hormone-releasing hormone in the brain of platyfish (Xiphophorus maculaus) as determined by immunocytochemistry. Cell Tissue. Res. 229, 7584.

Hamaguchi, S. (1979). The effect of methyltestosterone and cyproterone acetate on the proliferation of germ cells in the male fry of the Mekada, Oryzias latipes. J. Fac. Sci. Univ. Tokyo 14, 265272.

Higgs, D. A., Fagerlund, U. H. M., McBride, J. R., Dye, H. M., and Donaldson, E. M. (1977). Influence of combinations of bovine growth hormone, 17 amethyltestosterone and $\mathrm{I}$-thyroxine on growth of ycarling coho salmon Oncorhynchus kisutch. Canad. J. Lool. 55, 1048-1056.

Kallman, K. D., and Schreibman, M. P. (1973). A sexlinked gene controlling gonddotrop differentiation and its significance in determining the age of sexual maturation and size of the platyfish, Xiph ophorus maculatus. Gen. Comp. Endocrinol. 21, 287-304.

Kallman, K. D., Schrcibman, M. P., and Borkoski, V. (1973). Genetic control of gonadotrop differentiation in the platyfish Xiphorus maculatus (Poeciliidae). Science (Washington, D.C.) 181, 678680.

Lefebvre, J. (1983). "Introduction aux analyses statistiques multidimensionnelles," 3è éd. augmentée d'exemples d'applications, Masson, Paris

Lefebvre, J., Boitard, M., and Rey, J. F. (1981). "Logiciels d'analyses statistiques multidimensionnelles sur micro-ordinateurs." Masson, Paris.

McBride, J. R., and Fagerlund, U. H. M. (1973). The use of $17 \alpha$-methyltestosterone for promoting weight increases in juvenile pacific salmon. $J$. Fish. Res. Board Canad. 30, 1099-1104.

Olivereau, M. (1967). Observation sur l'hypophyse de l'Anguille femelle en particulier lors de la maturation sexuelle. $Z$. Zeilforsch. 80, 286-306.

Olivereau, M., and Chambolle, P. (1978). Ultrastructure des cellules gonadotropes de l'Anguille normale ct après injection d'oestradiol. C.R. Hebd. Seances Acad. Sci. Ser. D. 287, 1409-1412.

Olivereau, M., and Chambolle, P. (1979). Ultrastructure of gonadotrophs in the eel following oestradiol treatment. Proc. Indian Natl. Sci. Acad. B 45(5), 478-482.

Olivereau, M., and Fontaine, M. (1966). Etude cytologique de l'hypophyse de l'Anguille femelle mûre. C.R. Seances Soc. Biol. Ses I'il. 160, 13741378.

Olivereau, M., and Olivereau, J. (1979a). Effect of oestradiol- $17 \beta$ on the cytology of the liver, gonads and pituitary, and on plasma electrolytes in the female freshwater eel. Cell Tissue Res. 199, 431454.

Olivereau, M., and Olivereau, I. (1979b). Estradiol positive feedback on gonadotropic (GTH) cells in freshwater male silver eels. Gen. Comp. Endocrinol. 39, 247-261.

Pandey, S. (1969). The role of the pituitary and gonadal hormones in the differentiation of testis and secondary sex characters of the juvenile guppy, Poecilia reticulata peters. Biol. Reprod. 1, 272-281.

Pantic, V., and Lovren, M. (1978). The effects of fcmale gonadal steroids on carp pituitary gonadotropic cells and oogenesis. Folia Anat. Iugoslavica $7,25-34$

Schreck, C. B., and Fowler, L. G. (1982). Growth and reproductive development in fall chinook salmon: Effects of sex hormones and their antagonists. Aquaculture 26, 253-263.

Schreibman, M. P., and Kallman, K. D. (1978). The genetic control of sexual maturation in the teleost Xiphophorus maculatus (Pocciliidae). Ann. Biol. Anim., Biochim., Biophys. 18(4), 957-962.

Schrcibman, M. P., Margolis-Kazan, H., and HalpernSebold, L. (1982a). Immunoreactive gonadotropin and luteinizing hormone releasing hormone in the pituitary gland of neonalal platyfish. Gen. Comp. Endocrinol. 47, 385-391.

Schreibman, M. P., Margolis-Kazan, H., Halpern-Sebold, L., and Goos, H. J. Th. (1982b). The functional significance of the nucleus olfactoretinalis in the platyfish, Xiphophorus maculatus. In "Pro. ceedings, International Symposium on Reproductive Physiology of Fish, Wageningen, the Netherlands, 2-6 August 1982 (C. J. J. Richter and H. J. Th. Goos, eds, , p 59. Pudoc, Wageningen.

Sokolowska, M., Epler, P., and Bierniarz, K. (1978). The histological picture of the hypothalamus (the 
nucleus preopticus) and hypophysis in male $A n$ guilla anguilla L. treated with hormones. $J$. Fish. Biol. 12, 1-4.

Solari, A., Lefebvre, J., and Caillol, M. (1982). Application des Méthodes d'analyses multidimensionnelles à l'étude des variations du comportement sexuel et des stéroïdes ovaricns chez la lapine pseudogestantc. In "Actes du dixième Colloque Informatique et biosphère, " 169-187.

Sower, S. A., Schreick, C. B., and Evenson, M. (1983). Effects of steroids and steroids antagonists on growth, gonadal development and RNA/DNA ratios in juveniles steelhead trout. Aquaculture 32, 243-254.

Stuart-Kregor, P. A. C., Sumpter, J. P., and Dodd, J. M. (1981). The involvement of gonadotropin and sex steroids in the control of reproduction in the parr and adults of Atlantic salmon, Salmo salar L. J. Lïsh Biol. 18, 59-72.

Takahashi, H. (1972). Methyl testosterone induced differentiation of a seminal vesicle homologue in juvenile goldfish, Carassius auratus L. Growth Differ. 14, 297-305.

Ueda, H., and Takahashi, H. (1978). Changes of pituitary gonadotrophs associatcd with artificial maturation in silver females of the japanese eel, Anguilla japonica. Bull. Fac. Fish. Hokkaido Univ. 29(4), 299-307.
Upadhyay, S. N. (1977), "'Morphologie des gonades immatures et étude expérimentale de l'induction de la gamétogénèse chez la Truitc arc-en-ciel juvénile Salmo gairdneri R." Thèse de Doctorat d'Etat cs Sciences Naturelles-Paris VI.

Van den Hurk, R., and Van de Kant, H. (1975). The effect of methyl testosterone, 11-ketotestosterone and methallibure on gonadotropic cells, Leydig cells, spermatogenesis and the epithelium of the intratesticular efferent duct system of the juvenile black molly Mollienisia latipinna. Proc. Kon. Ned. Alad. Wetensch. Ser. C 78, 275-285.

Van Overbreeke, A. D., and McBride, J. R. (1971). Histological effects of 11-ketotestosterone, $17 a$ methyltestosterone, estradiol, estradiol cypionate and cortisol on the interrenal tissue, thyroid gland and pituitary gland of gonadectomized sockeye salmon Oncorhynchus nerka. J. Fish. Res. Board Canad. 28, 477-484.

Yamazaki, F. (1972). Effects of mcthyl testosterone on the skin and the gonad of salmonids. Gen. Comp. Endocrinol. Suppl. 3, 741-750.

Yu, T C., Sinnhuber, R. U., and Hendricks, J. D. (1979). Effect of steroid hormones on the growth of juvenile coho salmon Oncorhynchus kisutch. Aquaculture 16, 351-359. 